\title{
Perilaku Pemilihan Makanan dan Pengenalan Anggota Koloni pada Semut Rangrang Oecophylla smaragdina
}

\author{
Food Preference and Nestmate Recognition of Weaver Ants \\ Oecophylla smaragdina
}

\author{
M. UBAIDILAH HASAN, LA ODE FITRADIANSYAH, FERA SUSANTI, RIKA RAFFIUDIN*

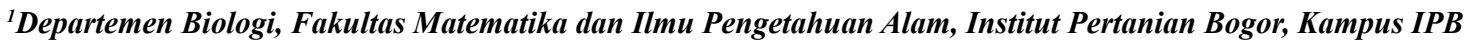 \\ Dramaga, Bogor 16680
}

Diterima 16 Juni 2021/Disetujui 2 November 2021

\begin{abstract}
Weaver ants Oecophylla smaragdina are social insects that recognize nestmates using pheromone. This study analyzes the feeding behavior and nestmate recognition of weaver ants in the urban area of three different islands (Sumatra: Baturaja; Java: Banyuwangi; Papua: Sorong). The free ants were placed in the arena composed of chicken meat, sugar, bananas as the baits. Ten trapped ants were also located in the arena to explore the nestmate recognition between the free and the trapped ants. Five types of behaviors, i.e., approach, stalking, communication, competition, and agonistic, were recorded in 6 days. Food preferences were indicated by the number of conduct towards the feeding sites, and nestmate recognition was indicated by approaching the trapped nestmate. The results showed that the percentage of the approach behavior of free ants was the highest in the three islands but had no significant difference between Sumatra and Java and between Java and Sorong (p-value $>0.05$ ). However, the study showed significant differences for the other four behaviors observed. As predicted, the percentage of chicken meat foraged by the ants was the highest due to the carnivorous behavior. The free ants showed the nestmate recognition to the trapped ants in all behavior, except competition.
\end{abstract}

Key words: Food preferences, Nestmate recognition, Agonistic behavior, Pheromone, Urban

\section{PENDAHULUAN}

Oecophylla smaradigna merupakan semut rangrang yang tersebar luas di Asia, Papua Nugini dan Australia dan hidup di derah iklim tropis termasuk Indonesia (Wetterer 2017). Semut $O$. smaragdina telah diternakkan petani di perkebunan buah (van Mele dan Cuc 2000), karena bersifat karnivor sehingga menjadi predator bagi serangga hama (Peng et al. 1995; Forbes dan Northfield 2017).

Setelah semut pengintai menemukan lokasi makanan, semut akan menandai lokasi tersebut menggunakan feromon, kemudian kembali ke sarang untuk merekrut anggota koloninya (Li et al. 2014). Eksperimen perilaku makan $O$. smaragdina telah dilakukan untuk menguji preferensi pakan dengan jenis yang berbeda yang menunjukkan semut ini lebih memilih pakan yang mengandung protein seperti tuna dan daging ayam (Pimid et al. (2019) dan Rezki et al. (under review).
Semut dapat mengenali anggota koloni melalui berbagai jenis senyawa Cuticular Hydrocarbons (CHC) yang dikeluarkan dari kutikula serangga (Raj et al. 2017). Hal ini tampak pada percobaan semut yang bebas dalam arena mendekati semut yang diperangkap (Khairussyifa et al. 2019).

Aktivitas semut mencari makan selain dipengaruhi faktor internal seperti rasa lapar (Howard dan Tschinkel 1980) juga dipengaruhi faktor eksternal seperti suhu pada semut Solenopsis invicta (Porter dan Tschinkel 1987) dan kelembapan pada semut Linepithema humile (Burford et al. 2018). Penelitian O. smaragdina di wilayah urban telah dilakukan oleh Rizali et al. (2008) dan Rezki et al. (under review), namun belum ada penelitian di Indonesia yang membandingkan antar pulau untuk pemilihaan makanan dan pengenalan anggota koloni. Oleh karena itu, penelitian ini bertujuan menganalisis pemilihan pakan dan pengenalan anggota koloni semut rangrang $O$. smaragdina di Sumatera, Baturaja; Jawa, Banyuwangi; dan Papua, Sorong.

*Penulis korespondensi:

E-mail: rika.raffiudin@apps.ipb.ac.id 


\section{BAHAN DAN METODE}

Lokasi dan Waktu. Penelitian dilakukan pada bulan April 2021 selama enam hari di masingmasing lokasi urban dari pulau yang berbeda (Sumatera, Jawa, danPapua). SampelO. smaragdina berasal dari Baturaja, Provinsi Sumatera Selatan (47'47.9064"S 104¹4'46.6836"E); Banyuwangi, Provinsi Jawa Timur $\left(8^{\circ} 23^{\prime} 25.0^{\prime \prime S} 114^{\circ} 18^{\prime} 08.3^{\prime \prime E}\right)$; dan Sorong, Provinsi Papua Barat $\left(0^{\circ} 56^{\prime} 52.8^{\prime \prime S}\right.$ 13120'25.6"E) (Gambar 1).

Prosedur Eksperimen. Semua sampel semut yang digunakan pada penelitian ini adalah dari kasta pekerja $O$. smaragdina dengan menggunakan dua koloni. Sarang semut yang ditemukan dalam penelitian ini masuk kategori di lokasi urban, karena interaksi manusia yang tinggi dan jarak pohon yang ada di lokasi tersebut tidak membentuk kanopi (Rezki et al. under review). Sarang semut pada masing-masing lokasi memiliki karakteristik yang berbeda-beda (Gambar 1 dan Tabel 1).
Arena percobaan terbuat dari kertas karton putih yang berisi umpan berupa tiga jenis pakan, yaitu daging ayam, gula, dan pisang putri [Musa ascuminata] (Gambar 2). Pengamatan pada semut $O$. smaragdina dilakukan untuk perilaku mengintai, mendekati, pada pemberian umpan dan juga komunikasi, dan agonistik antar koloni. Perilaku kompetisi diamati untuk kompetisi di dalam koloni dan di luar koloni (Tabel 2).

Dua puluh individu semut pekerja ditangkap menggunakan tangan (hand collection) dan semut diletakkan di arena percobaan yang ditutup gelas plastik terbalik. Arena diletakkan di teras rumah pada masing-masing lokasi tiap pulau. Arena di Sorong terletak di area yang lebih tertutup dibanding dua lokasi lain. Jarak antara lokasi arena percobaan dengan lokasi sarang semut di Baturaja (koloni 1:1.2 km dan koloni 2:600 m); Banyuwangi (koloni 1:10 m dan koloni 2:17 m); dan Sorong (koloni 1:5 m dan koloni 2:10 m) (Gambar 3).
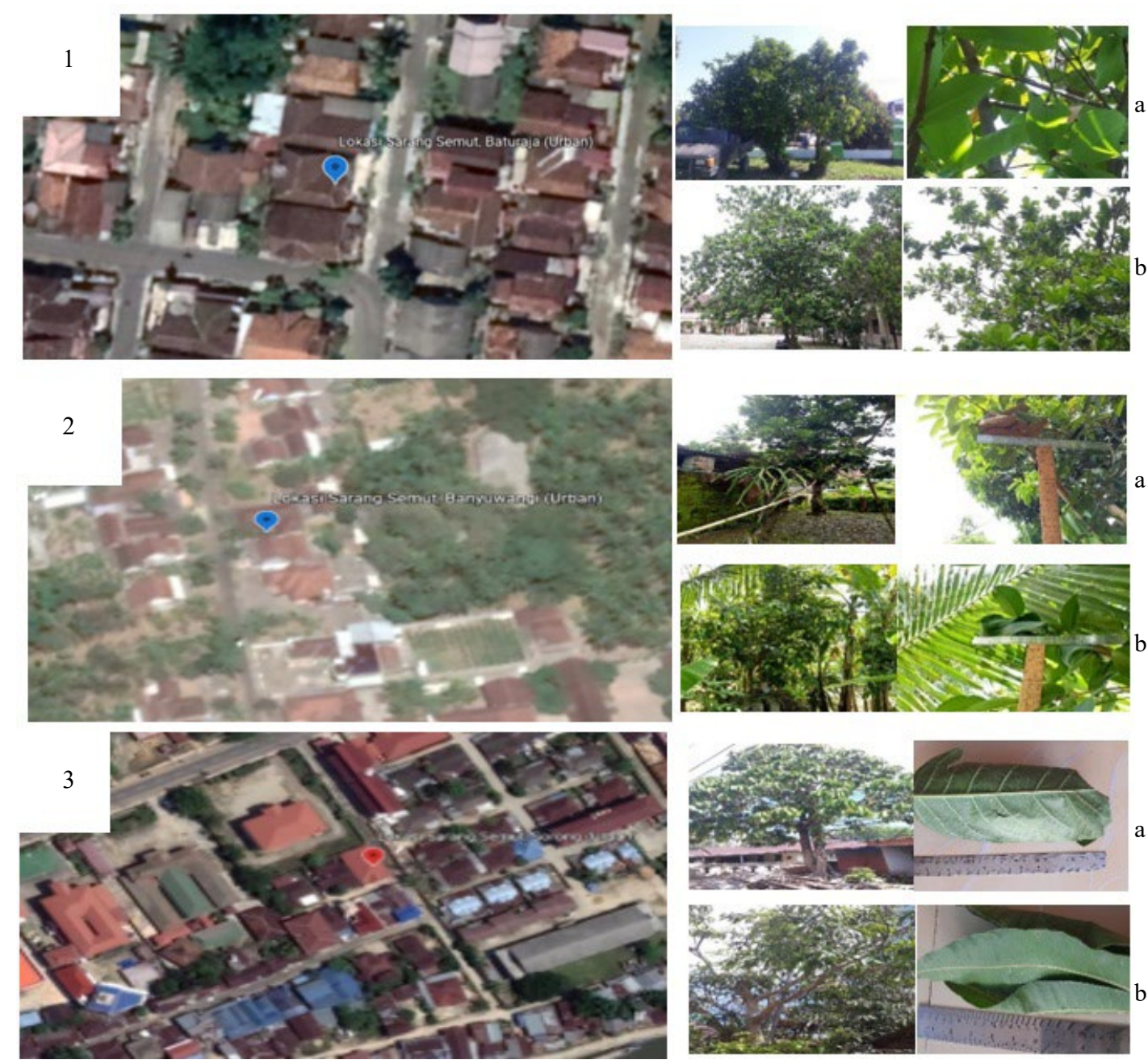

Gambar 1. Lokasi penelitian daerah urban: 1 = Baturaja, 2 = Banyuwangi, dan 3 = Sorong (lokasi sarang semut: $\mathrm{a}=$ koloni $1, \mathrm{~b}=$ koloni 2) 
Tabel 1. Deskripsi sarang semut $O$. smaragdina di tiga lokasi urban

\begin{tabular}{|c|c|c|}
\hline \multirow{2}{*}{ Lokasi } & \multicolumn{2}{|c|}{ Deskripsi sarang } \\
\hline & Koloni 1 & Koloni 2 \\
\hline Banyuwangi & $\begin{array}{l}\text { Pohon rambutan (Nephelium lappaceum), ketinggian } \\
3.5 \mathrm{~m} \text {, sarang tersusun dari daun yang sudah kering }\end{array}$ & $\begin{array}{l}\text { Pohon jambu air (Syzygium aqueum), ketinggian } 5 \mathrm{~m} \text {, } \\
\text { sarang tersusun dari daun yang masih segar }\end{array}$ \\
\hline Sorong & $\begin{array}{l}\text { Pohon jambu air (Syzygium aqueum), ketinggian } 2.8 \mathrm{~m} \text {, } \\
\text { sarang tersusun dari daun yang masih segar }\end{array}$ & $\begin{array}{l}\text { Pohon mangga (Mangifera sp.), ketinggian } 2 \mathrm{~m} \text {, sarang } \\
\text { tersusun dari daun yang masih segar }\end{array}$ \\
\hline Baturaja & $\begin{array}{l}\text { Pohon jambu air (Syzygium aqueum), ketinggian } 2.5 \mathrm{~m} \text {, } \\
\text { sarang tersusun dari daun yang masih segar }\end{array}$ & $\begin{array}{l}\text { Pohon ketapang (Terminalia sp.); ketinggian } 3.5 \mathrm{~m} \text {, sarang } \\
\text { tersusun dari daun yang masih segar }\end{array}$ \\
\hline
\end{tabular}

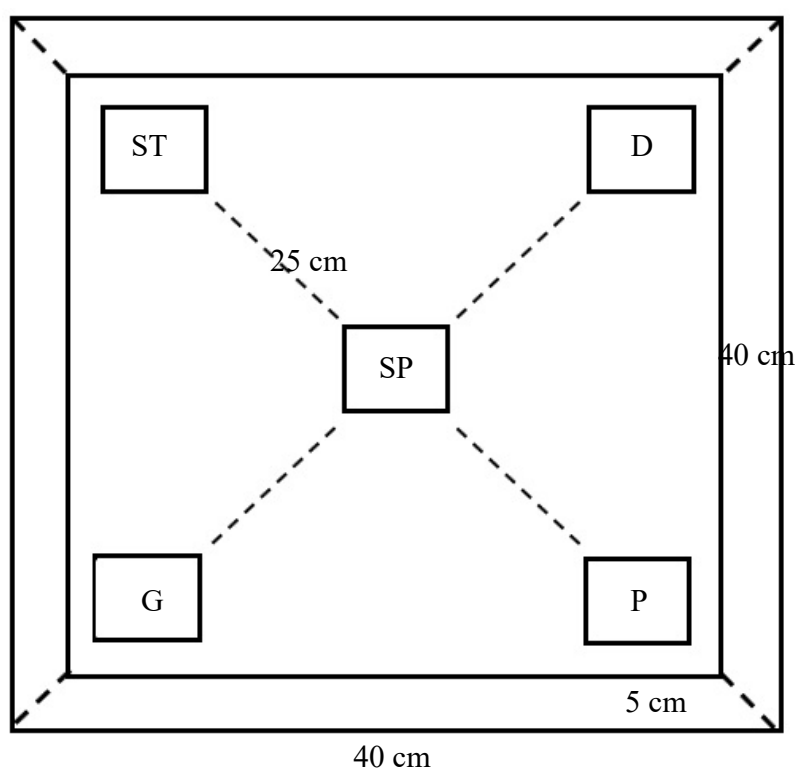

Gambar 2. Arena percobaan ( $\mathrm{SP}=$ Semut pengamatan yang bebas: 10 individu diletakkan di tengah arena dengan jarak $\pm 25 \mathrm{~cm}$ dari tepi, $\mathrm{ST}=$ Anggota koloni terperangkap, $\mathrm{D}=$ Daging ayam, $\mathrm{G}=$ Gula, dan $\mathrm{P}=$ Pisang)

Tabel 2. Ethogram perilaku makan semut $O$. smaragdina terhadap pemberian tiga jenis pakan dan pengenalan anggota koloni $(\mathrm{a}=$ Hardiyanti et al. $2015 ; \mathrm{b}=$ Kamhi et al. 2015; c = Rezki et al.. (under review)).

\begin{tabular}{|c|c|c|}
\hline Perilaku & Perilaku & Pustaka \\
\hline Mengintai & $\begin{array}{l}\text { Semut mendekati pakan dengan jarak } \\
>2 \mathrm{~cm} \text { dan }<5 \mathrm{~cm} \text {, tanpa menyentuh } \\
\text { pakan }\end{array}$ & $\mathrm{a}, \mathrm{c}$ \\
\hline Mendekati & $\begin{array}{l}\text { Semut mendekati pakan dan menyentuh } \\
\text { pakan dengan antena }\end{array}$ & $\mathrm{a}, \mathrm{c}$ \\
\hline Komunikasi & $\begin{array}{l}\text { Semut menempelkan antena ke antena } \\
\text { semut lain yang sebelumnya semut } \\
\text { tersebut mendekati pakan }\end{array}$ & $\mathrm{c}$ \\
\hline Kompetisi & $\begin{array}{l}\text { Perebutan pakan dengan spesies semut } \\
\text { lain }\end{array}$ & $\mathrm{c}$ \\
\hline Agonistik & $\begin{array}{l}\text { Semut menunjukkan postur ancaman } \\
\text { ke semut lain dengan rahang melebar } \\
\text { dan gasternya naik, kemudian } \\
\text { menggigit }\end{array}$ & $\mathrm{a}, \mathrm{b}$ \\
\hline
\end{tabular}

Dari 20 individu semut pekerja yang ditangkap, 10 individu diperangkap di pojok arena yang sejajar dengan pakan (ST) dan 10 individu diletakkan di tengah arena untuk dibebaskan dan diamati perilakunya (SP) (Gambar 2). Semut SP dicatat perilaku terhadap tiga jenis pakan dan pengenalan dengan anggota koloni semut yang diperangkap (ST). Pemilihan pakan didasarkan semut menyukai daging ayam dan gula (Rezki et al. under review).

Pengamatan dan Pencatatan Perilaku Pemilihan Pakan. Perilaku pemilihan pakan semut diamati dengan metode all occurrence sampling (Altman 1974). Deskripsi perilaku makan mengikuti Hardiyanti et al. (2015), Kamhi et al. (2015), dan Pimid et al. (2019) (Tabel 2). Pengamatan dan pencatatan dimulai jam 09.0010.00 am WIB (Sumatera Selatan dan Jawa Timur) dan WIT (Papua Barat) ketika semut di tengah arena dilepaskan. Perlakuan diulang sebanyak tiga kali dengan 10 individu semut SP yang berbeda untuk tiap perlakuan. Suhu dan kelembapan udara diukur menggunakan thermo-hygrometer pada saat pengamatan.

Analisis Data. Perbedaan persentase perilaku pemilihan pakan dan pengenalan anggota koloni dianalisis menggunakan uji Kruskal-wallis. Uji Post Hoc metode Bonferroni digunakan untuk signifikansi data. Uji korelasi Spearman digunakan untuk menganalisis hubungan perilaku makan dengan suhu dan kelembapan. Data dianalisis melalui Program Excel 2019 dan R-studio v.4.0.5. (R Core Team 2015).

HASIL

Deskripsi Perilaku Pemilihan Pakan dan Pengenalan Anggota Koloni Semut O. smaragdina. Perilaku mengintai, mendekati, dan komunikasi pakan didapatkan pada semua semut $O$. smaragdina (Gambar 


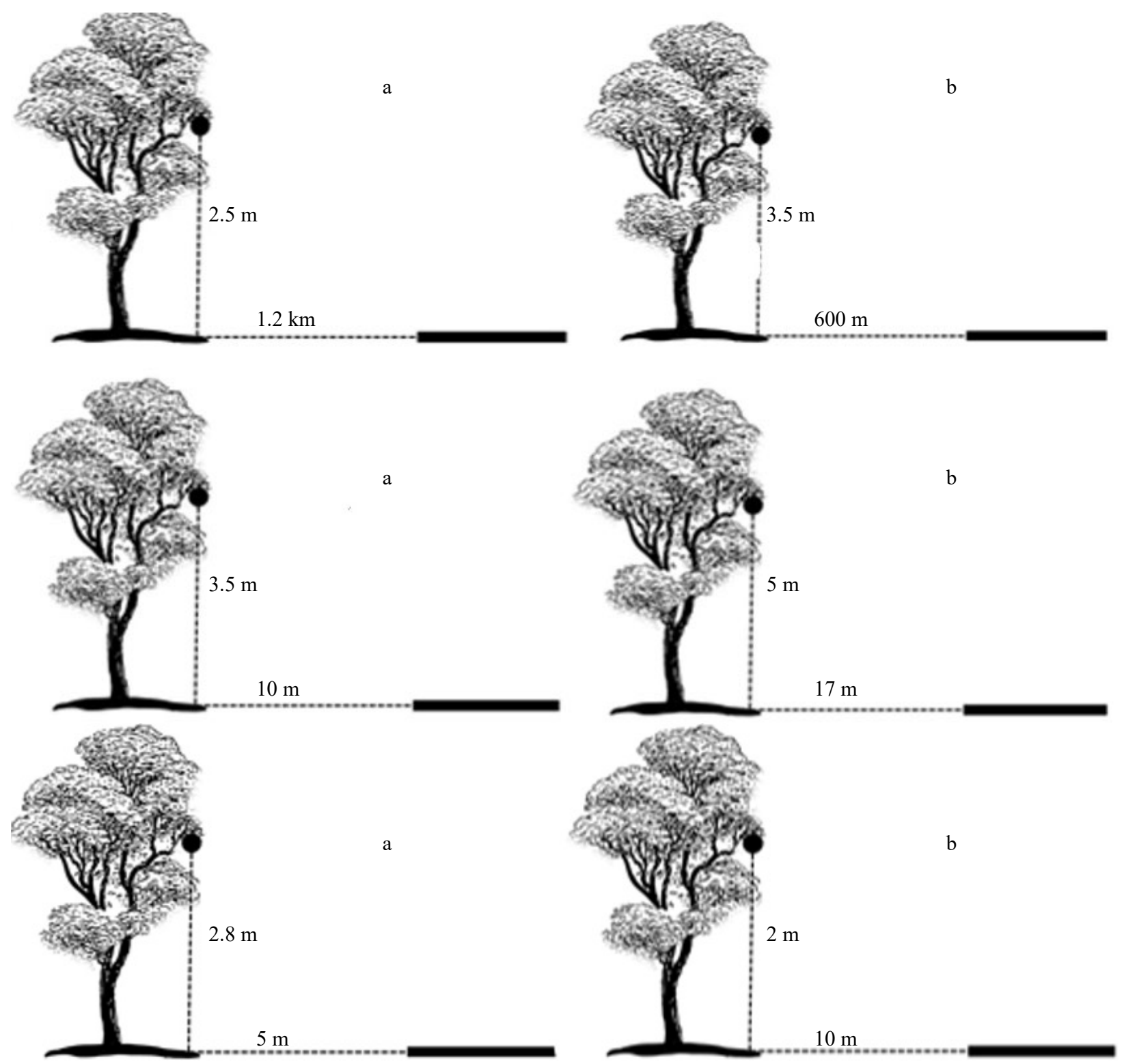

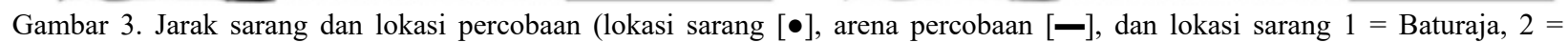
Banyuwangi, 3 = Sorong di koloni $1=$ a dan koloni $2=b$ )

4a-c) di tiga lokasi urban (Baturaja, Banyuwangi, dan Sorong). Perilaku agonistik juga terjadi antar anggota koloni semut rangrang di Baturaja dan Sorong (Gambar 4d). Pada percobaan di Banyuwangi, terdapat semut dari spesies lain masuk ke arena percobaan dan memperlihatkan perilaku kompetisi dengan $O$. smaragdina memperebutkan daging ayam (Gambar 4e).

Perilaku mengintai adalah perilaku yang pertama muncul ketika semut berjarak $\pm 2-4 \mathrm{~cm}$ dari lokasi umpan. Perilaku semut mengintai pakan (Gambar 4a) diikuti dengah perilaku semut mendekati dengan menyentuhkan antenanya (Gambar 4b). Setelah mendekati umpan, beberapa semut melakukan komunikasi dengan anggota koloninya dengan menyentuhkan antena antara satu semut dengan semut yang lain (Gambar 4c). Perilaku agonistik juga terjadi antar anggota koloni SP dengan cara menggigit bagian abdomen semut yang lain (Gambar 4d).

Persentase Perilaku Pemilihan Pakan dan Pengenalan Anggota Koloni. Persentase perilaku mendekati merupakan perilaku yang paling sering muncul dibandingkan dengan semua perilaku (Gambar 5). Hal tersebut didukung durasi tertinggi perilaku mendekati dibandingkan perilaku lainnya (Tabel 3). Perilaku semut antara tiga lokasi urban menunjukkan signifikansi perbedaan $(p$-value $<0.05)$ saat mengintai, komunikasi, kompetisi, dan agonistik, sedangkan tidak untuk perilaku mendekati ( $p$-value $>0.05$ ) (Tabel 4).

Perilaku semut mendekati pakan lebih tinggi ke daging ayam daripada yang lain. Perilaku pemilihan makan semut di Baturaja dan Banyuwangi terjadi di semua jenis pakan, kecuali perilaku makan ke pisang tidak terjadi di Sorong (Gambar 6). 

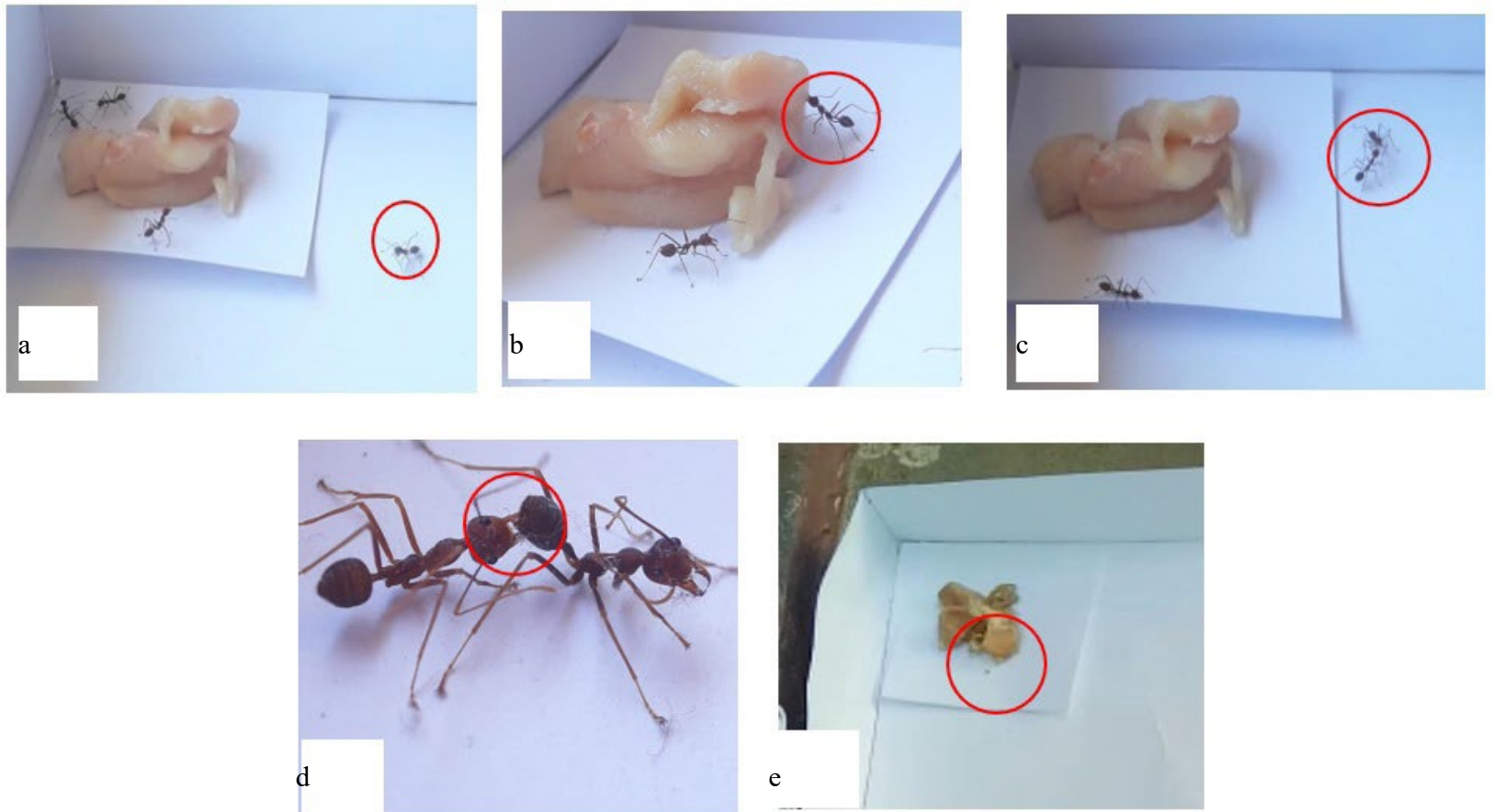

Gambar 4. Perilaku O. smaragdina yang diamati: $\mathrm{a}=$ mengintai, $\mathrm{b}=$ medekati, $\mathrm{c}=$ komunikasi, $\mathrm{d}=$ agonistik, dan $5=$ kompetisi

Tabel 3. Rataan dan standar deviasi durasi perilaku (detik) semut $O$. smaragdina di ketiga lokasi penelitian

\begin{tabular}{|c|c|c|c|c|c|c|}
\hline \multirow{2}{*}{ Perilaku } & \multicolumn{3}{|c|}{ Koloni 1} & \multicolumn{3}{|c|}{ Koloni 2} \\
\hline & Baturaja & Banyuwangi & Sorong & Baturaja & Banyuwangi & Sorong \\
\hline Mengintai & $41 \pm 3$ & $42 \pm 2$ & $39 \pm 1$ & $41 \pm 1$ & $40 \pm 2$ & $41 \pm 4$ \\
\hline Mendekati & $119 \pm 1$ & $120 \pm 4$ & $121 \pm 1$ & $124 \pm 2$ & $123 \pm 5$ & $119 \pm 4$ \\
\hline Komunikasi & $21 \pm 3$ & $21 \pm 2$ & $17 \pm 1$ & $13 \pm 3$ & $20 \pm 2$ & $23 \pm 1$ \\
\hline Kompetisi & $0 \pm 0$ & $33 \pm 3$ & $0 \pm 0$ & $0 \pm 0$ & $30 \pm 2$ & $0 \pm 0$ \\
\hline Agonistik & $23 \pm 20$ & $0 \pm 0$ & $11 \pm 19$ & $25 \pm 22$ & $0 \pm 0$ & $11 \pm 18$ \\
\hline
\end{tabular}

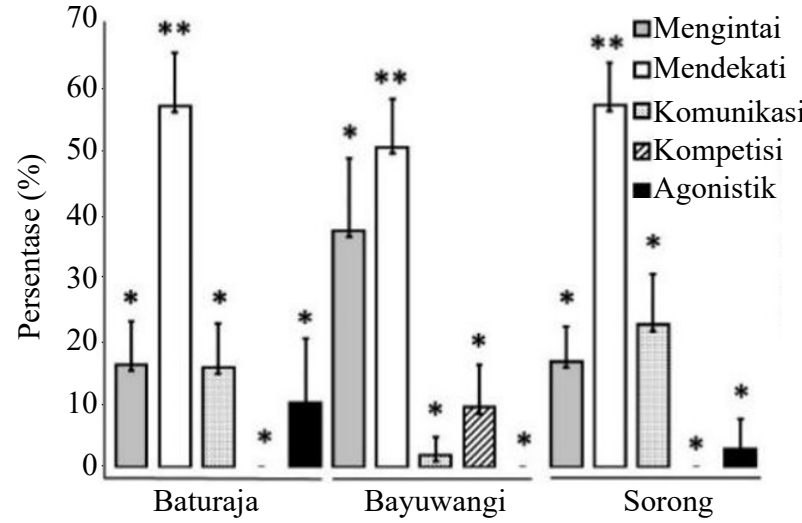

Gambar 5. Persentase perilaku semut $O$. smaragdina di tiga lokasi urban (tanda * = ada perbedaan dan tanda ** $=$ tidak ada perbedaan)

\section{Korelasi Perilaku Pemilihanan Pakan dengan}

Faktor Lingkungan. Pengukuran parameter lingkungan di tiga lokasi mendapatkan data kisaran suhu $28-31{ }^{\circ} \mathrm{C}$ dan kelembapan $55-75 \%$ (Tabel 4). Berdasarkan hasil analisis uji korelasi Spearman, perilaku semut yang berkorelasi dengan suhu adalah kompetisi, komunikasi, dan agonistik, sedangkan yang tidak berkorelasi adalah mengintai dan mendekati. Perilaku semut yang berkorelasi dengan kelembapan adalah kompetisi dan agonistik, sedangkan yang
Tabel 4. Signifikansi perilaku semut $O$. smaragdina antara tiga lokasi urban (tanda $*=$ berbeda secara signifikan)

\begin{tabular}{llll}
\hline Perilaku & $p$-value & $\begin{array}{l}\text { Signifikansi } \\
\text { antara lokasi }\end{array}$ & $p$-value \\
\hline Mengintai & 0.003257 & Baturaja-Banyuwangi & $0.0055^{*}$ \\
& & Baturaja-Sorong & 1,000 \\
& & Banyuwangi-Sorong & $0.0046^{*}$ \\
\hline Mendekati & 0.1893 & Baturaja-Banyuwangi & - \\
& & Baturaja-Sorong & - \\
& & Banyuwangi-Sorong & - \\
\hline Komunikasi & 0.001536 & Baturaja-Banyuwangi & 0.0289 \\
& & Baturaja-Sorong & 0.3466 \\
& & Banyuwangi-Sorong & $0.0006^{*}$ \\
\hline Kompetisi & 0.0003035 & Baturaja-Banyuwangi & $0.0007^{*}$ \\
& & Baturaja-Sorong & 1,000 \\
& & Banyuwangi-Sorong & $0.0007^{*}$ \\
\hline Agonistik & 0.0488 & Baturaja-Banyuwangi & $0.0216^{*}$ \\
& & Baturaja-Sorong & 0.2347 \\
& & Banyuwangi-Sorong & 0.4541 \\
\hline
\end{tabular}

tidak berkorelasi adalah mengintai, mendekati dan komunikasi (Tabel 5).

\section{PEMBAHASAN}

Perilaku semut $O$. smaragdina mendekati umpan adalah perilaku yang paling sering muncul, kemudian diikuti oleh perilaku mengintai, komunikasi, dan 

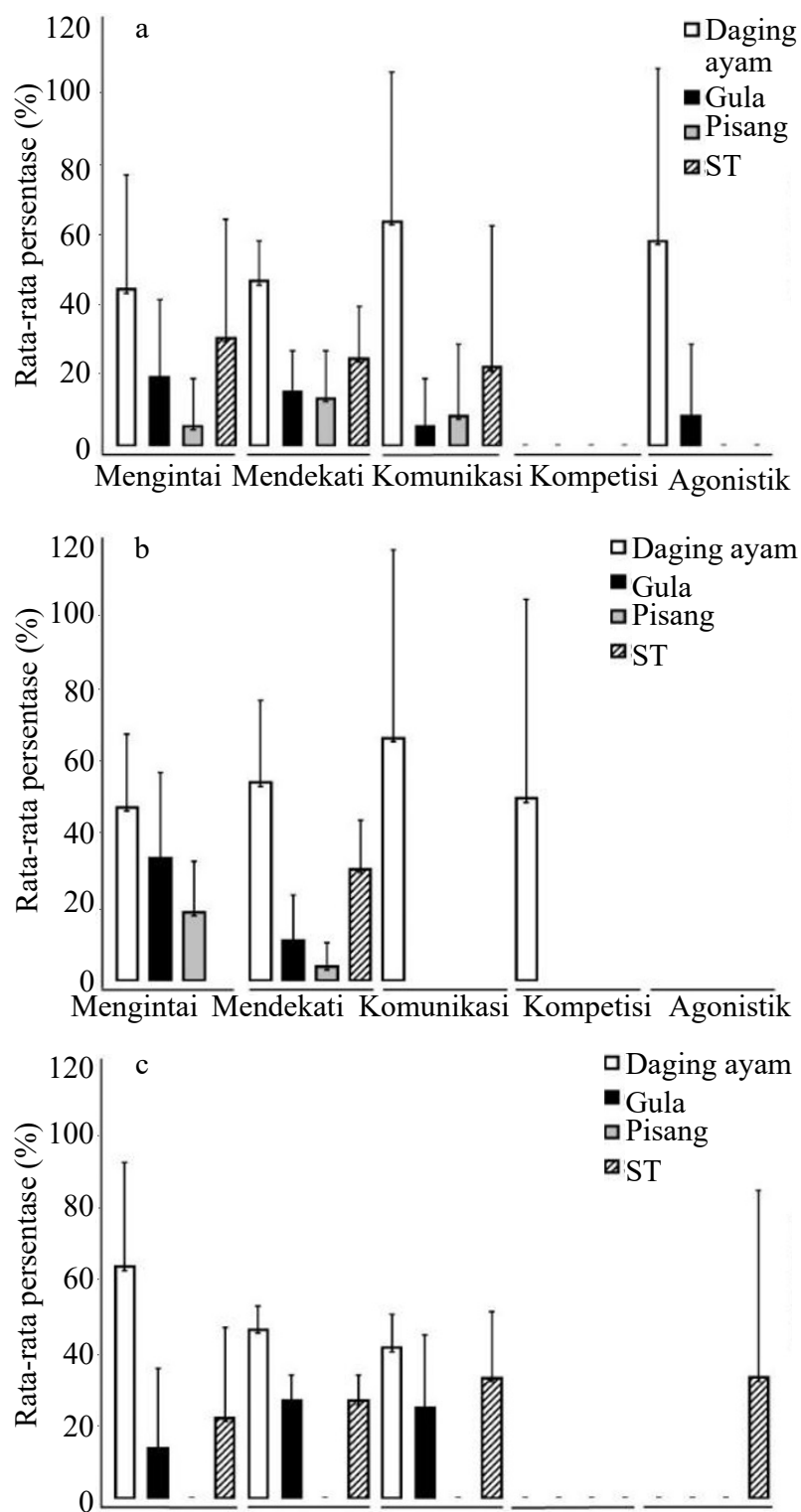

Mengintai Mendekati Komunikasi Kompetisi Agonistik Gambar 6. Persentase perilaku O. smaragdina dalam memilih pakan di tiga lokasi $(\mathrm{a}=$ Baturaja, $\mathrm{b}=$ Banyuwangi, dan $\mathrm{c}=$ Sorong)

Tabel 5. Korelasi perilaku semut $O$. smaragdina dari seluruh lokasi urban dengan parameter suhu dan kelembapan (tanda $*=$ terdapat korelasi)

\begin{tabular}{lcc}
\hline Perilaku & $p$-value suhu & $p$-value Kelembapan \\
\hline Mengintai & 0.1324 & 0.9366 \\
Mendekati & 0.782 & 0.4294 \\
Komunikasi & $3.19 \mathrm{E}-14^{*}$ & $1.67 \mathrm{E}-14^{*}$ \\
Kompetisi & $0.006882^{*}$ & 0.9509 \\
Agonistik & $1.62 \mathrm{E}-07^{*}$ & $1.62 \mathrm{E}-07^{*}$ \\
\hline
\end{tabular}

agonistik. Semut pengintai setelah menemukan lokasi makanan kembali ke sarang untuk merekrut anggota koloni menuju lokasi pakan (Li et al. 2014). Rekrutmen semut SP di arena (Gambar 4b dan c) melibatkan perilaku komunikasi yang menyebabkan terjadinya perilaku semut rekrutan mendekati pakan yang sama (Bradshaw et al. 1979). Pada semut pada $O$. longinoda sekresi senyawa 1-heksanol dari kelenjar mandibula menjadi alarm feromon untuk menarik anggota koloni ke sumber lokasi pakan
(Bradshaw et al. 1979). Jumlah maksimal individu $O$. smaragdina yang direkrut ke sumber pakan bervariasi antara 25 hingga 59 individu dan hanya 9 sampai 19 individu semut yang bertugas mengambil (Holldobler 1983).

Perilaku pemilihan pakan semut $O$. smaragdina di tiga lokasi urban lebih sering terjadi ke daging ayam dibandingkan pakan lain. Hasil ini sesuai dengan Rezki et al. (under review) pada daging ayam dan Pimid et al. (2019) pada daging tuna. Semut $O$. smaragdina yang bersifat karnifor juga sering digunakan sebagai agen pengendali biologis untuk manajemen hama (Falahudin 2012; Forbes dan Northfield 2017) diantaranya Lipaphis erysimi, Maconellicoccus hirsutus, dan Raphidopalpa foveicollis (Bhagat et al. 2020). Perilaku predator O. smaragdina terjadi melalui tiga tahap (Pierre dan Idris 2013) yaitu pertama, semut mengidentifikasi mangsa dari kejauhan yang ditandai dengan naiknya gaster membentuk sudut 900 . Kedua, semut bergerak ke arah mangsa dan menggigitnya, lalu mengeluarkan asam format (formic acid) saat gaster ditinggikan melengkung ke depan. Ketiga, mangsa diangkat untuk dibawa ke sarang setelah mangsa berhasil dikendalikan.

Suhu luar di lokasi sarang relatif tinggi $\left(28-31^{\circ} \mathrm{C}\right)$ dengan kelembapan yang rendah (55-75\%), karena sarang terletak pada lokasi urban yang memiliki sedikit pepohonan. O. smaragdina merupakan semut rangrang yang aktivitasnya berhubungan dengan suhu (Mishra dan Bhadani 2017) dan kelembapan (Burford et al. 2018). Akan tetapi, perilaku makan O. smaragdina di dalam kultur toleran terhadap suhu dan kelembapan, serta jika populasinya kecil aktivitasnya dipengaruhi oleh angin di awal sore hari (Greenslade 1972).

Semut SP berperilaku mengintai, mendekati, dan komunikasi ke arah semut ST di lokasi Baturaja dan Sorong, sedangkan perilaku mendekati hanya terjadi di Banyuwangi (Gambar 4a-c). Senyawa Cuticular Hydrocarbons (CHC) yang merupakan campuran dari n-alkana, monometill alkana, dan dimetil alkana membantu semut $O$. smaragdina dalam pengenalan anggota koloni (Raj et al. 2017). Perilaku membuka mandibula merupakan perilaku indikator agresif semut Pachycondyla analis terhadap anggota bukan koloni dengan pemberian senyawa CHC (Yusuf et al. 2010). Kondisi semut $\mathrm{ST}$ yang masih hidup memungkinkan senyawa $\mathrm{CHC}$ bekerja dalam mengenali anggota koloni semut $O$. smaragdina di arena, baik semut ST maupun semut SP. Senyawa CHC akan menghilang ketika semut Linepithema humile mati (Choe et al. 2009).

Perilaku agonistik antara semut SP terjadi di Baturaja (Gambar 4d) dan semut SP di Sorong menunjukkan perilaku agonist ke semut ST (pengamatan pribadi) yang keduanya memperlihatkan perilaku mengigit abdomen anggota koloninya. Kandungan Cuticular Hydrocarbons (CHC) merupakan komponen pengenalan yang dapat membedakan antar koloni sehingga terjadi 
agresifitas terjadi antar koloni. (Ozaki et al. 2005). Komposisi hidrokarbon yang berbeda mengakibatkan agresifitas terjadi antara anggota koloni Linepithema humile (Suarez et al. 2002). Agresifitas juga lebih tinggi terjadi pada semut $O$. smaragdina yang memiliki sensilia lebih banyak di antena (Gill et al. 2013). Agresifitas juga terjadi pada antara anggota koloni semut Cataglyphis niger, namun persentasenya lebih rendah daripada dengan koloni lain (Lahav et al. 1999).

Perilaku kompetisi hanya terjadi di Banyuwangi, karena letak arena lebih terbuka dan dekat dengan pepohonan serta tanah dibandingkan arena di lokasi lain. Kondisi ini memungkinkan semut spesies lain yang ukurannya lebih kecil berkompetisi dengan O. Smaragdina (pengamatan pribadi). Kompetisi dilakukan dengan memakan daging ayam secara berhadapan tanpa ada interaksi tarik menarik. Cara kompetisi ini berbeda dengan Rezki et al. (under review). Kompetisi pada sumber pakan juga terjadi antara semut kasta pekerja Camponotus brutus dengan Polyrhachis laboriosa (Mercier dan Dejaen 1996). Semut P. laboriosa melakukan kompetisi dengan cara mengeksplorasi keberadaan C. brutus, dan setelah merasakan kehadirannya $P$. laboriosa bergerak menuju C. brutus. P. laboriosa menyentakkan tubuh, dan menunjukkan posisi pertahanan dengan cara menekukkan gaster (Mercier dan Dejaen 1996).

\section{DAFTAR PUSTAKA}

Altmann J. 1974. Observational study of behavior: sampling methods. Behaviour 49:227-266. https://doi. org/10.1163/156853974X00534

Bhagat M. Ganguli J. Gauraha R. 2020. Predatory behaviour of red ant (Oecophylla smaragdina F.) on various insect pests of different crops. Journal of Entomology and Zoology Studies 8:1396-1400.

Bradshaw JWS. Baker R. Howse PE. 1979. Multicomponent alarm pheromones in the mandibular glands of major workers of the African weaver ant, Oecophylla longinoda. Physiological Entomology 4:15-25. https:// doi.org/10.1111/j.1365-3032.1979.tb00173.x

Burford BP, Lee G, Friedman DA, Brachmann E, Khan R, MacArthur-Waltz DJ, McCarty AD. Gordon DM. 2018. Foraging behavior and locomotion of the invasive Argentine ant from winter aggregations. PloS One 13:p. e0202117.https://doi.org/10.1371/journal.pone.0202117

Choe DH, Millar JG, Rust MK. 2009. Chemical signals associated with life inhibit necrophoresis in Argentine ants. Proceedings of the National Academy of Sciences 106:8251-8255. https://doi.org/10.1073/pnas.0901270106

Falahudin I. 2012. Peranan semut rangrang (Oecophylla smaragdina) dalam pengendalian biologis pada perkebunan kelapa sawit. Annual International Conference on Islamic Studies (AICIS) XII, 5:2604-2618.

Forbes SJ. Northfield TD. 2017. Oecophylla smaragdina ants provide pest control in Australian cacao. Biotropica 49:328-336. https://doi.org/10.1111/btp.12405

Gill KP, van Wilgenburg E, Macmillan DL, Elgar MA. 2013. Density of antennal sensilla influences efficacy of communication in a social insect. The American Naturalist 182:834-840. https://doi.org/10.1086/673712
Greenslade PJM. 1972. Comparative ecology of four tropical ant species. Insectes Sociaux 19:195-212. https://doi. org/10.1007/BF02226626

Hardiyanti, Yusminah H, Eka PT. 2015. Identifikasi pola perilaku pada semut Jepang dewasa. Bionature 16:63-68.

Holldobler B. 1983. Territorial behavior in the green tree ant (Oecophylla smaragdina). Biotropica 15:241-250. https:// doi.org/10.2307/2387648

Howard DF, Tschinkel WR. 1980. The effect of colony size and starvation on food flow in the fire ant, Solenopsis invicta (Hymenoptera: Formicidae). Behav Ecol Sociobiol 7: 293-300. https://doi.org/10.1007/BF00300670

Kamhi JF, Nunn K, Robson SKA, Traniello JFA. 2015. Polymorphism and division of labour in a socially complex ant: neuromodulation of aggression in the Australian weaver ant, Oecophylla smaragdina. Proceedings of the Royal Society B: Biological Sciences 282:20150704. https://doi.org/10.1098/rspb.2015.0704

Khairussyifa N, Fitri ZA, Ratna I. 2019. Pengujian kesetiaan semut: antara teman dan makanan (ant's loyalty test: between mate and meat). Indonesian Fun Science Journal 1:67-76.

Lahav S, Soroker V, Hefetz A, Vander Meer RK. 1999. Direct behavioral evidence for hydrocarbons as ant recognition discriminators. Naturwissenschaften 86:246-249. https:// doi.org/10.1007/s001140050609

Li L, Peng H, Kurths J, Yang Y, Schellnhuber HJ. 2014. Chaosorder transition in foraging behavior of ants. Proceedings of the National Academy of Sciences 111: 8392-8397. https://doi.org/10.1073/pnas.1407083111

Mercier JL. Dejean A. 1996. Ritualized behavior during competition for food between two Formicinae. Insectes Sociaux 43:1729. https://doi.org/10.1007/BF01253952

Mishra M, Bhadani S. 2017. Daily activity and visual discrimination reflects the eye organization of weaver ant Oecophylla smaragdina (Insecta: Hymenoptera: Formicidae). BioRxvi. https://doi.org/10.1101/193243

Ozaki M, Wada-Katsumata A, Fujikawa K, Iwasaki M, Yokohari F, Satoji Y, Nisimura T, Yamaoka R. 2005. Ant nestmate and non-nestmate discrimination by a chemosensory sensillum. Science 309:311-314. https://doi.org/10.1126/ science. 1105244

Peng RK, Christian K, Gibb K. 1995. The effect of the green ant, Oecophylla smaragdina (Hymenoptera: Formicidae), on insect pests of cashew trees in Australia. Bulletin of Entomological Research 85:279-284. https://doi. org/10.1017/S0007485300034374

Pierre EM, Idris AH. 2013. Studies on the predatory activities of Oecophylla smaragdina (Hymenoptera: Formicidae) on Pteroma pendula (Lepidoptera: Psychidae) in oil palm plantations in Teluk Intan, Perak (Malaysia). Asian myrmecology 5:163-176.

Pimid M,Ahmad AH, Krishnan KT, Scian J. 2019. Food preferences and foraging activity of asian weaver ants, Oecophylla smaragdina (Fabricius) (Hymenoptera: Formicidae). Trop Life Sci Res 30:167-179. https://doi.org/10.21315/ tlsr2019.30.2.12

Porter SD, Tschinkel WR. 1987. Foraging in Solenopsis invicta (Hymenotpera: Formicidae): effects of waether and season. Environ Entomol 16:802-808. https://doi.org/10.1093/ ee/16.3.802

R Core Team. 2015. R: A language and environment for statistical computing. R Foundation for Statistical Computing, Vienna, Austria. Tersedia di: https://www.R-project.org [Tanggal diakses: 17 Mei 2021] 
Raj RA, Sathish R, Prakasam A, Krishnamoorthy D, Balachandar M, Tomson M. 2017. Extraction and analysis of cuticular hydrocarbons in the weaver ant Oecophylla smaragdina (Fabricius) (Hymenoptera: Formicidae). International Journal of Fauna and Biological Studies 4:102-107.

Rezki, Oliya N, Fadhliansyah, Wulndari SL, Jesajas DR, Raffiudin R. (under review). Perilaku mencari makan pada semut rangrang (Oecophylla smaragdina). Scripta Biologica.

Rizali A, Bos MM, Buchori D, Yamane S, Schulze CH. 2008. Ants in tropical urban habitats: the myrmecofauna in a densely populated area of Bogor, West Java, Indonesia. HAYATI Journal of Biosciences 15:77-84. https://doi. org/10.4308/hjb.15.2.77

Suarez AV, Holway DA, Liang D, Tsutsui ND, Case TJ. 2002. Spatiotemporal patterns of intraspecific aggression in the invasive Argentine ant. Animal Behaviour 64:697-708. https://doi.org/10.1006/anbe.2002.4011 van Mele P, Cuc NTT. 2000. Evolution and status of Oecophylla smaragdina (Fabricius) as a pest control agent in citrus in the Mekong Delta, Vietnam. International Journal of Pest Management 46:295-301. https://doi. org/10.1080/09670870050206073

Wetterer JK. 2017. Geographic distribution of the weaver ant Oecophylla smaragdina. Asian myrmecology 9:1-12.

YusufAA, Pirk CW, Crewe R. N Njagi PG, Gordon I, Torto B. 2010. Nestmate recognition and the role of cuticular hydrocarbons in the African termite raiding ant Pachycondyla analis. Journal of chemical ecology 36:441-448. https://doi. org/10.1007/s10886-010-9774-6 